\title{
INTEGRACJA INSTYTUCJONALNA W KRAJACH UNII EUROPEJSKIEJ. PROPOZYCJA POMIARU
}

\section{WSTĘP}

Ostatnie dwa dziesięciolecia były okresem fundamentalnych przemian instytucjonalnych w Europie. W przypadku krajów Europy Środkowo-Wschodniej przemiany te dotyczyły zarówno sfery politycznej, jak i głębokiej przebudowy fundamentów życia gospodarczego. Każdy z krajów regionu, wybierając transformację w kierunku gospodarki rynkowej oraz podejmując trud integracji europejskiej, był zmuszony do gruntownej przebudowy istniejącego porządku instytucjonalnego. Jednak zmiany instytucjonalne w sferze gospodarczej nie ograniczały się tylko i wyłącznie do tzw. krajów transformacji ${ }^{1}$. W ciągu ostatnich dwóch dekad także rozwinięte kraje tzw. starej Europy były zmuszone do podjęcia trudu reform instytucjonalnych odnoszących się do porządku ekonomicznego, co z jednej strony było wymuszone przez intensyfikację zjawiska globalizacji oraz narastającą konkurencję gospodarczą w wymiarze międzynarodowym, której najbardziej namacalnym przejawem była przykładowo rosnąca rola krajów azjatyckich, a z drugiej strony wiązało się z wspomnianymi zmianami polityczno-gospodarczymi w Europie Środkowo-Wschodniej.

Innym znamiennym zjawiskiem ostatnich lat, które musiało wywrzeć istotny wpływ na przemiany instytucjonalne w Europie, jest tzw. rewolucja informacyjna. Prawdopodobnie nigdy wcześniej nie istniała na świecie infrastruktura technologiczna i społeczna ${ }^{2}$, która pozwałaby na tak szybką jak obecnie dyfuzję wiedzy

1 Sformułowanie „kraje transformacji” zostało tutaj użyte w oderwaniu od pytania: czy tzw. transformacja systemowa krajów Europy Środkowo-Wschodniej jest już procesem zakończonym.

2 Określenie „infrastruktura technologiczna” odnosi się do wszystkich narzędzi teleinformatycznych z Internetem na czele, które sprzyjają zwiększaniu tempa przepływu informacji. Określenie „infrastruktura społeczna” odnosi się tutaj np. do zjawiska rosnącego przepływu ludzi. 
odnoszącej się do tzw. dobrych praktyk rządzenia i tworzenia reguł instytucjonalnych sprzyjających bądź ograniczających wzrost gospodarczy oraz poziom dobrobytu społecznego.

Powyższe zjawiska niewątpliwie należy zaliczyć do czynników stymulujących procesy integracyjne w sferze gospodarczej w Europie. W związku z tym celem niniejszej analizy jest sformalizowana ocena zjawiska integracji instytucjonalnej w odniesieniu do porządku gospodarczego w krajach Unii Europejskiej w pierwszym dziesięcioleciu XXI wieku.

Wszelkie próby pomiaru zjawisk o charakterze instytucjonalnym wiążą się z kluczowymi problemami metodycznymi odnoszącymi się do kwantyfikacji zjawisk, których istotą jest ich jakościowa natura i wielowymiarowy charakter. W związku z tym w niniejszym badaniu wykorzystano powszechnie uznane narzędzia analizy taksonomicznej.

\section{INTEGRACJA JAKO KONSEKWENCJA DĄŻENIA DO PODNIESIENIA EFEKTYWNOŚCI ŁADU INSTYTUCJONALNEGO W WARUNKACH GLOBALNEJ GOSPODARKI WIEDZY}

Douglas C. North definiuje instytucje jako ograniczenia zachowań ludzkich, mające wpływ na jakość interakcji. Instytucje obejmują formalne zasady zachowania i regulacje, nieformalne ograniczenia (normy zachowań, konwenanse, wzory postępowania) i są źródłem restrykcji w zakresie zawierania umów pomiędzy aktorami życia gospodarczego. W ten sposób instytucje wpływają na efektywność gospodarczą, determinując transakcje i koszty transakcyjne działalności gospodarczej ${ }^{3}$. W rezultacie $z$ perspektywy długookresowej wystąpienie wszystkich czynników będących podstawą wzrostu gospodarczego i podniesienia dobrobytu społecznego, jak np. intensyfikacja postępu technologicznego, wzrost jakości kapitału ludzkiego oraz rozwój przedsiębiorczości, jest możliwe tylko w sytuacji osiągnięcia progowej efektywności system instytucjonalnego, która gwarantuje wystarczająco niski poziom kosztów transakcyjnych w gospodarce ${ }^{4}$.

Uwarunkowania instytucjonalne, w szczególności odnoszące się do nieformalnych reguł głęboko zakorzenionych w świadomości społecznej, są zawsze konsekwencją długookresowego historycznego procesu formowania się, który może

3 D.C. North, Economic Performance through Time, „American Economic Review” 1994, vol. 84 , No. 3, s. 359 i passim.

4 Idem, Institutions, Transactions Cost and Productivity in the Long Run, Ecin WPA, Economic History 9309004, 1993, http://ideas.repec.org/e/prio11.html (28.03.2007 r.). 
trwać dziesiątki lub nawet setki lat ${ }^{5}$. Przeformułowanie tych reguł instytucjonalnych oraz pojawienie się procesów integracyjnych w tym zakresie jest zawsze bardzo trudne. Szczególny problem stanowi to, jeżeli określone reguły nieformalne stają się ważną destymulantą procesów rozwojowych w przypadku danego kraju. $\mathrm{Z}$ drugiej strony wiele elementów ładu instytucjonalnego odnoszących się do tzw. reguł stanowionych, takich jak np. ograniczenia prawne i wymogi związane z prowadzeniem działalności gospodarczej, regulacje formalne wpływające na poziom oraz charakterystyki intensywności konkurencji w określonych branżach lub na danych rynkach, jest konsekwencją niedawno „podjętych, jak również bieżących decyzji politycznych oraz wyborów społecznych. Te elementy ładu instytucjonalnego mogą być zazwyczaj modyfikowane w ciągu kilku lat. Tym samym podlegają one stosunkowo szybkim przemianom w związku z rozprzestrzenianiem się wiedzy dotyczącej dobrych praktyk rządzenia lub są zmieniane w wyniku występowania silnych bodźców egzogenicznych, takich jak rosnąca międzynarodowa presja konkurencyjna ${ }^{6}$. Oznacza to, że te elementy porządku instytucjonalnego moga podlegać procesom relatywnie szybkiej integracji.

Jednym z najważniejszych zjawisk ostatnich dziesięcioleci wpływających na zmiany powyższych „reguł gry gospodarczej” jest proces powstawania nowej globalnej gospodarki wiedzy. Obecnie ekonomiści zgadzają się, że ostatnie dwie dekady były czasem, w którym dochodziło do wyjątkowo szybkiej, głębokiej transformacji niemal wszystkich sektorów oraz gospodarek jako całości w przypadku wszystkich krajów wysoko rozwiniętych, a także większości krajów rozwijających się. Głównym czynnikiem prowadzącym do tych zmian jest rosnące znaczenie innowacji technologicznych $\mathrm{w}$ dziedzinie telekomunikacji i przetwarzania informacji. Tym zmianom paradygmatu technologicznego w sferze informacyjno-komunikacyjnej towarzyszą procesy reorganizacji podmiotów gospodarczych, rozwój oraz rosnąca dynamika rynków kapitałowych, coraz większe znaczenie indywidualnej przedsiębiorczości jako czynnika wzrostu gospodarczego, rosnąca zmienność rynków pracy oraz globalizacja prowadzącą do ciągłej i rosnącej konkurencji w wymiarze krajowym i międzynarodowym. Można stwierdzić, że te nowe warunki reprezentują fundamentalne odejście od narodowej, korporacyjnej gospodarki opierającej się na masowej produkcji dóbr, dominującej w krajach rozwiniętych od końca lat czterdziestych do końca lat siedemdziesiątych XX wieku. Obecna gospodarka stanowi globalną, opartą na wiedzy oraz przedsiębiorczości

O. Williamson, The New Institutional Economics: Taking Stock, Looking Ahead, „Journal of Economic Literature” 2000, vol. XXXVIII, s. 595-613.

6 A.P. Balcerzak, E. Rogalska, Government's Effectiveness in Creating Institutional Conditions for Entrepreneurship in Central and Eastern Europe in the Years 2004-2010, [w:] Policies for Improving Growth Potential: International Perspective, red. A.P. Balcerzak, Wydawnictwo Naukowe UMK, Toruń 2010, s. 49-55. 
gospodarkę, w której kluczowym czynnikiem sukcesu staje się zakres, w jakim wiedza, technologia i innowacja są zakorzenione w produktach i usługach ${ }^{7}$.

Powyżej opisane realia przyczyniły się do konieczności dostosowywania wielu sfer porządku instytucjonalnego zgodnie $\mathrm{z}$ wymogami nowych globalnych warunków gospodarowania w poszczególnych krajach, w których celem polityki społeczno-gospodarczej jest wykorzystanie potencjału związanego z nową globalną gospodarką. Do najważniejszych segmentów porządku instytucjonalnego, które wpływają na potencjał rozwojowy kraju w warunkach przedstawionej globalnej transformacji gospodarczej, należą: a) efektywność krajowych regulacji wspierających prywatną przedsiębiorczość; b) rola konkurencyjnego otoczenia oraz ład instytucjonalny rynku pracy; c) porządek instytucjonalny wpływający na efektywność rynku finansowego we wspieraniu rozwoju przedsiębiorstw o wysokim potencjale wzrostu; d) rozwiązania instytucjonalne pozwalające na rozwój zaplecza dla akumulacji wiedzy i własności intelektualnej ${ }^{8}$.

Obecnie nie ma kontrowersji $\mathrm{w}$ odniesieniu do stwierdzenia, że poziom przedsiębiorczości $\mathrm{w}$ danym kraju stanowi jeden z najważniejszych nienamacalnych czynników wzrostu gospodarczego ${ }^{9}$. Jest on zależny od wielu nieformalnych czynników instytucjonalnych formowanych w toku wielu dziesięcioleci, takich jak np. społeczne postrzeganie i zakres akceptacji społecznej dla indywidualnej przedsiębiorczości. Jednak doświadczenia ostatnich dziesięcioleci potwierdzają, że poziom krajowej przedsiębiorczości jest istotnie ujemnie skorelowany z czynnikami instytucjonalnymi o charakterze prawnym, które zwiększają zakres regulacji, są źródłem dodatkowych obciążeń i ograniczają swobodę działalności gospodarczej ${ }^{10}$. W rezultacie $\mathrm{w}$ ostatnich latach $\mathrm{w}$ wielu krajach można zauważyć

7 R.D. Atkinson, D.K. Correa, The 2007 State New Economy Index. Benchmarking Economic Transformation in the States, Kauffman Foundation, „The Information Technology and Innovation Foundation" 2007, February, s. 3.

8 Oczywiście zaproponowany wybór musi mieć charakter w znacznym stopniu arbitralny, o czym należy pamiętać przy jego interpretacji. Jest on efektem próby syntetycznego ujęcia wniosków płynących z literatury przedmiotu oraz powszechnie uznawanych międzynarodowych programów badawczych będących podstawą takich opracowan, jak: raport Wolność gospodarcza śrwiata przygotowywany przez ekonomistów pracujących pod auspicjami Instytutu Frasera, Indeks wolności gospodarczej tworzony przy wsparciu „The Wall Street Journal” i Heritage Foundation czy też globalne badanie dotyczące warunków prowadzenia działalności gospodarczej corocznie przygotowywane przez Bank Światowy. Zob. także: A.P. Balcerzak, Państwo w realiach „nowej gospodarki”. Podstawy efektywnej polityki gospodarczej w XXI wieku, Wydawnictwo Adam Marszałek, Toruń 2009, s. 289 i passim.

9 E. Okoń-Horodyńska, Przedsiębiorczośc jako niewykorzystane źródto sukcesu polskiej gospodarki, Polskie Towarzystwo Ekonomiczne, Warszawa 2009

10 S. Ardagna, A. Lusardi, Explaining International Differences in Entrepreneurship: the role of Indivitual Characters and Regulatory Constraints, NBER Working Papers Series, Working Paper 14012, 2008, May; A. Stel, D. Storey, A. Thurik, The Effect of Business Regulations on Nascent and Young Business Entrepreneurship, „Small Business Economics” 2007, vol. 28, No. 2, s. 171-186. 
znaczące reformy instytucjonalne, których celem jest tzw. uproszczenie warunków prowadzenia działalności gospodarczej.

Badania empiryczne prowadzone w ostatnich latach dowiodły, że w przypadku krajów odnoszących znaczące sukcesy w wykorzystaniu potencjału związanego z procesami globalnej transformacji, działalność regulacyjna państwa była ukierunkowana głównie na stworzenie wysoko konkurencyjnego ładu rynkowego. Wysoka presja konkurencyjna na krajowych rynkach jest kluczowym źródłem bodźców dla wysokiej innowacyjności w sferze technologicznej i organizacyjnej oraz zwiększa tempo dyfuzji przyjmowanych rozwiązań, co stanowi ważny stymulator podnoszenia produktywności gospodarki. Z kolei aktywność regulacyjna państwa w odniesieniu do rynków pracy nie powinna prowadzić do zwiększenia sztywności tego rynku. Nie powinna także koncentrować się na administracyjnej ochronie istniejących określonych miejsc pracy. Polityka rynku pracy powinna raczej zwiększać jego efektywność w zakresie łączenia strony popytowej z podażową przez obniżanie kosztów transakcyjnych. Działania państwa powinny stanowić pomoc dla osób tracących swoje miejsca pracy w okresie przejściowym oraz zwiększać ich możliwości znalezienia nowego zatrudnienia, przy jednoczesnym ograniczeniu prawdopodobieństwa uzależnienia się beneficjenta od pomocy państwowej ${ }^{11}$.

Ważnym czynnikiem dynamizującym wzrost gospodarczy krajów rozwiniętych, którego rola istotnie zwiększa się, jest funkcjonowanie nowych wysoce innowacyjnych przedsiębiorstw o dużym potencjalne wzrostu gospodarczego. Przedsiębiorstwa te stają się ważnym nośnikiem zarówno rozwoju, jak i dyfuzji nowych technologii oraz przyczyniają się do przyspieszenia tempa zmian technologicznych. Funkcjonowanie takich podmiotów gospodarczych jest ściśle związane z efektywnością ładu instytucjonalnego rynków finansowych, które powinny przyczyniać się do szybkiej realokacji kapitału z tzw. tradycyjnych dojrzałych branż o niskim potencjale wzrostu do branż o wysokim potencjalne rozwojowym ${ }^{12}$.

Współczesna globalna gospodarka wiedzy jest także coraz bardziej uzależniona od wytwarzania produktów nienamacalnych, w przypadku których głównym źródłem wartości dodanej jest zakumulowana w nich wiedza i wartości intelektualne. $Z$ tego względu rozwój krajów, które zamierzają uczestniczyć w procesie

11 A.P. Balcerzak, Wptyw dziatalności regulacyjnej państwa w obszarze kreowania tadu konkurencyjnego na rozwój nowej gospodarki [w:] Aktywność regulacyjna państwa a potencjat rozwojowy gospodarki, red. A.P. Balcerzak, M. Moszyński, Polskie Towarzystwo Ekonomiczne Oddział w Toruniu, Toruń 2009, s. 71-102.

12 Zob. A.P. Balcerzak, Structure of Financial Systems and Development of Innovative Enterprises with High Grow Potential, [w:] Global Challenges and Politics of the European Union - Consequences for the "New Member States", red. M. Piotrowska, L. Kurowski, Prace Naukowe Uniwersytetu Ekonomicznego we Wrocławiu, nr 59, Wrocław 2009, s. 30-39. 
budowania i podnoszenia efektywności w sferze gospodarki opartej na wiedzy jest ściśle związany $\mathrm{z}$ kształtem i efektywnością ładu instytucjonalnego w sferze ochrony praw własności intelektualnej ${ }^{13}$.

W rezultacie w części empirycznej niniejszej pracy analiza procesów integracyjnych w krajach Unii Europejskiej będzie się odnosić do powyżej scharakteryzowanych sfer ładu instytucjonalnego.

\section{METODYKA BADANIA}

Wywód przeprowadzony w poprzednim podpunkcie pozwala na stwierdzenie, że ład instytucjonalny stanowi z jednej strony zjawisko trudno kwantyfikowalne, $\mathrm{z}$ drugiej strony próba jego pomiaru powinna uwzględniać jego wielowymiarowy charakter. Oznacza to, że w przypadku propozycji sformalizowanych analiz empirycznych, których celem są porównania międzynarodowe w odniesieniu do zmian specyfik systemów instytucjonalnych poszczególnych krajów, konieczne jest wykorzystanie narzędzi analizy wielowymiarowej. W przypadku niniejszego badania zostało wykorzystane instrumentarium taksonomiczne. W literaturze analogiczne podejście było stosowane $\mathrm{w}$ odniesieniu do badania instytucjonalnych ram polityki pieniężnej ${ }^{14}$ oraz instytucjonalnych warunków wspierających potencjał innowacyjny kraju ${ }^{15}$.

W niniejszym badaniu wykorzystano narzędzia taksonomiczne w celu uzyskania grupowań według kryteriów instytucjonalnych krajów będących członkami Unii Europejskiej przy wykorzystaniu hierarchicznej metody klasyfikacji. Pozwoliło to na uzyskanie jednorodnych podzbiorów krajów ze względu na kształt systemu instytucjonalnego w poszczególnych latach. Takie jednorodne podzbiory określane są jako skupienia. Definiuje się je jako zbiór obiektów, które są do siebie podobne, w tym samym czasie są one jednak istotnie różne od obiektów należących do innych skupień. Jako miarę podobieństwa wykorzystano odległość między obiektami ${ }^{16}$. W badaniu wykorzystano dane roczne $\mathrm{z}$ okresu 2000-2008 dla 27 krajów będących członkami UE ${ }^{17}$. Pozwoliło to na uchwyce-

13 Kapitat intelektualny i jego ochrona, red. E. Okoń-Horodyńska, R. Wisła, Instytut Wiedzy i Innowacji, Warszawa 2009.

14 J. Pietrucha J., Ramy instytucjonalne polityki pieniężnej-teoria i pomiar, Wydawnictwo Akademii Ekonomicznej w Katowicach, Katowice 2008, s. 228-236.

15 K. Piech, Wiedza i innowacje w rozwoju gospodarczym: w kierunku pomiaru $i$ wspótczesnej roli państwa, Instytut Wiedzy i Innowacji, Warszawa 2009, s. 287-394.

16 Zob. Statystyczne metody analizy danych, red. W. Ostasiewicz, Wydawnictwo Akademii Ekonomicznej im. Oskara Langego, Wrocław 1998, s. 86-108.

17 Cały zbiór danych wykorzystanych w badaniu pochodzi z bazy Instytutu Frasera tworzonej na potrzeby raportu Wolność gospodarcza świata. Rok 2008 był ostatnim rokiem, dla którego do- 
nie okresu czterech lat przed oraz czerech lat po największym rozszerzeniu Unii Europejskiej. Ocena zmian składu skupień w badanych latach analizy może być pomocna $\mathrm{w}$ ukazaniu przekształceń uwarunkowań instytucjonalnych oraz procesów integracji w sferze gospodarczego porządku instytucjonalnego w badanych krajach. Główne zagadnienie badawcze niniejszej analizy sprowadzało się do pytania: czy w analizowanym okresie można mówić o procesie upodabniania się w sferze instytucjonalnej tzw. starych i nowych krajów członkowskich Unii Europejskiej?

$\mathrm{Z}$ oczywistych względów w badaniu tego typu nie ma możliwości wyeliminowania groźby subiektywnej oceny, która jest związana $z$ doborem zmiennych diagnostycznych służących ilościowemu opisowi różnych sfer porządku instytucjonalnego. Jednak, dążąc do minimalizacji ryzyka $\mathrm{z}$ tym związanego, zrezygnowano $\mathrm{z}$ ważenia mierników odnoszących się do poszczególnych segmentów ładu instytucjonalnego, zrezygnowano także $z$ tworzenia rankingów systemów instytucjonalnych poszczególnych krajów oraz skupiono się na próbie oceny ich podobieństwa.

W pierwszej fazie badania zostały wybrane zmienne diagnostyczne spełniające kryteria merytoryczno-formalne ${ }^{18}$, które pozwalają na ocenę różnych aspektów ładu instytucjonalnego w badanych krajach zgodnie z konwencją bazującą na rozważaniach w poprzednim podpunkcie. Na tej podstawie wyselekcjonowano zbiór potencjalnych miernikow diagnostycznych, zakwalifikowanych do czterech grup $^{19}$ :

stępny był pełen zestaw danych w przypadku ostatniej dostępnej w momencie wykonywania badań publikacji z roku 2010. Zob. J. Gwartney, J. Hall, R. Lawson, Economic Freedom of the World 2010 Annual Report, Fraser Institute, 2010. Alternatywnym źródłem danych dla niniejszego badania mogłyby być bazy Banku Światowego wykorzystywane przy tworzeniu raportu dotyczącego warunków prowadzenia działalności gospodarczej. Baza Instytutu Frasera została wybrana na potrzeby badań, gdyż oferuje ona możliwość wydłużenia okresu badania oraz charakteryzuje się większą stabilnością metodologiczną niż baza Banku Świtowego. Zob. Doing Business 2011. Making Difference for Entrepreneurs, The International Bank for Reconstruction and Development/The World Bank, Washington 2010.

18 Do kryteriów tych należy zaliczyć: uniwersalność i mierzalność zmiennych, dostępność i jakość danych liczbowych, ekonomiczność i interpretowalność zmiennych oraz dokonanie sprawdzenia sposobu oddziaływania zmiennych. Zob. Taksonomiczna analiza przestrzennego zróżnicowania poziomu życia w Polsce w ujęciu dynamicznym, red. A. Zeliaś, Wydawnictwo Akademii Ekonomicznej, Kraków 2000, s. 37-38.

19 W badaniu zastosowano zestaw wskaźników zbliżony do wykorzystanych w przypadku analizy efektywności instytucjonalnej państwa w sferze wspierania wykorzystania potencjału nowej globalnej gospodarki wiedzy przeprowadzonej przez Adam Balcerzaka. Ze względu na brak danych dla drugiej połowy okresu badania nie uwzględniono tu miernika stopnia kontroli stopy procentowej odnoszącego się do segmentu c) Rynek finansowy a rozwój przedsiębiorstw o wysokim potencjale wzrostu, który był uwzględniony w cytowanym badaniu. Zob. A.P. Balcerzak, Państwo w realiach, s. 289-290. 
a) Regulacja nastawiona na wspieranie przedsiębiorczości:

$x_{i 1}$ - administracyjne ograniczenia rozpoczęcia działalności gospodarczej oraz warunki wejścia do nowej branży;

$x_{i 2}$ - czas niezbędny na czynności biurokratyczne związane z prowadzeniem działalności gospodarczej;

$x_{i 3}$ - koszty rozpoczęcia nowej działalności gospodarczej;

$x_{i 4}$ - efektywność systemu regulowania zobowiązań finansowych;

$x_{i 5}$ - niezależność systemu sądowniczego;

$x_{i 6}$ - bezstronność systemu sądowniczego;

$x_{i 7}$ - ogólny poziom praworządności.

b) Znaczenie konkurencyjnego otoczenia oraz elastyczności rynku pracy:

$x_{i 8}$ - dotkliwość regulacji wpływających na swobodę kształtowania się cen;

$x_{i 9}$ - regulacyjne ograniczenia swobody handlu;

$x_{i 10}$ - ekonomiczne konsekwencje istnienia płacy minimalnej;

$x_{i 11}$ - ograniczenia swobody zawierania umów o pracę;

$x_{i 12}$ - udział zatrudnionych otrzymujących płace ustalane w ramach zbiorowych negocjacji płacowych w grupie osób pracujących.

c) Rynek finansowy a rozwój przedsiębiorstw o wysokim potencjale wzrostu:

$x_{i 13}$ - poziom konkurencji w sektorze bankowym;

$x_{i 14}$ - dostępność kredytu.

d) Instytucjonalne zaplecze dla akumulacji wiedzy i wtasności intelektualnej:

$x_{i 15}$ - efektywność systemu ochrony praw własności intelektualnej.

Powyższe wskaźniki poddano ocenie ze względu na kryteria wartości informacyjnej zmiennych. Według tych kryteriów zmienne diagnostyczne powinny charakteryzować się wystarczająco dużą zmiennością przestrzenną, ważnością oraz niską korelacją.

Pierwsze kryterium oznacza, że zmienne nie powinny być do siebie podobne pod względem informacji o obiektach. Zmienność przestrzenna cech może być oceniona przy wykorzystaniu współczynnika zmienności. Eliminuje się cechy, dla których wartość współczynnika będzie niższa od przyjętej wartości progowej. Zazwyczaj z badania eliminuje się zmienne, dla których wartość współczynnika zmienności jest niższa o np. $10 \%{ }^{20}$.

Potencjalne zmienne diagnostyczne uznawane są za ważne, jeżeli trudno osiągają wysokie wartości. Dla oceny ważności można stosować współczynnik asymetrii. Przy założeniu, że zmienna jest stymulantą ${ }^{21}$, dla cech ważnych rozkład

20 Statystyczne metody analizy, s. 115-116.

21 Zmienna jest stymulantą, jeśli dla każdych dwóch jej wartości $\mathrm{x}_{i j}, \mathrm{x}_{j k}$ odnoszących się do obiektów $\mathrm{A}_{i}, \mathrm{~A}_{k}$ zachodzi $\mathrm{x}_{i j}>\mathrm{x}_{j k} \Rightarrow A_{i} \succ A_{k}$, przy czym $\succ$ oznacza, że obiekt $\mathrm{A}_{i}$ jest preferowany $\operatorname{nad} \mathrm{A}_{k}$. M. Walesiak, Uogólniona miara odlegtości w statystycznej analizie wielowymiarowej, Wydawnictwo Akademii Ekonomicznej im. Oskara Langego, Wrocław 2002, s. 16-19. 
cechy powinien być prawostronnie asymetryczny. Dla stymulanty rozkład cechy lewostronnie asymetryczny oznacza, że większość z obiektów osiąga wysoki stopień nasycenia w przypadku danego miernika. Tym samym cecha ta nie różnicuje silnie badanych obiektów, powinna zatem zostać wyeliminowana $\mathrm{z}$ badania. Alternatywnym podejściem do badania rozkładów cech jest analiza dystrybuanty empirycznej. W tym przypadku podstawą oceny ważności cechy jest wypukłość dystrybuanty. Klasyfikację przeprowadza się na podstawie wielkości $t_{j}$, gdzie ważność cechy rośnie wraz ze zmniejszaniem się wartości wskaźnika. Jako progową wartość wskaźnika można stosować np. $0,5^{22}$. W badaniu wykorzystano pierwsze z omawianych podejść.

Silna korelacja pomiędzy zmiennymi diagnostycznymi oznacza powtarzanie się informacji. W przypadku wystąpienia zbyt wysokiego stopnia skorelowania cech zazwyczaj dokonuje się wyboru zmiennych reprezentantek. W tym celu można zastosować np. parametryczną metodę Hellwiga, gdzie jako progowy poziom współczynnika korelacji przyjmuje się np. $r^{*}=0,8^{23}$.

Tabela 1 przedstawia zmienne diagnostyczne, które w poszczególnych latach nie spełniały kryterium wysokiej zmienności przestrzennej. Zgodnie z formalnymi wskazaniami stosowanego kryterium ze względu na częstotliwość pojawiania się zmiennych $x_{i 3}$ i $x_{i 9}$ w zbiorach niespełniających kryterium zmienności przestrzennej należałby rozważyć ich wyeliminowanie $z$ dalszego badania ${ }^{24}$. Odnosząc się jednak do celu badania, którym jest ocena procesów integracyjnych w sferze instytucjonalnej, już na tym etapie należy wskazać na interesujące zjawisko. W maju 2004 r. odbyło się największe rozszerzenie Unii Europejskiej. Konsekwencje tego rozszerzenia związane $z$ ujednoliceniem regulacji wpływających na koszty rozpoczęcia nowej działalności gospodarczej oraz przepisów prowadzących do ograniczania swobody handlu są bardzo silnie dostrzegalne w przypadku analizowanych mierników dla badanych krajów. Od roku 2005 nastąpiło zmniejszenie zmienności badanych mierników, co można interpretować jako konsekwencje implementacji przepisów wspólnotowych, tym samym może to być traktowane jako przejaw procesów integracyjnych w odniesieniu do gospodarczego ładu prawnego.

Tabela 1. Zmienne diagnostyczne niespełniające kryterium wysokiej zmienności przestrzennej

\begin{tabular}{|c|c|c|c|c|c|c|c|c|}
\hline Rok & 2001 & 2002 & 2003 & 2004 & 2005 & 2006 & 2007 & 2008 \\
\hline Zmienne & - & - & - & - & $x_{i 3}, x_{i 9}$, & $x_{i 3}, x_{i 9}$ & $x_{i 3}, x_{i 9}$ & $x_{i 3}, x_{i 9}$ \\
\hline
\end{tabular}

Źródło: obliczenia własne.

22 Ibidem, s. 116-117

23 K. Strzała, T. Przechlewski, Ekonometria inaczej, Wydawnictwo Uniwersytetu Gdańskiego, Gdańsk 1995, s. 154-156

24 Taksonomiczna analiza, s. 126-133 
Zgodnie ze wskazanymi postulatami ważności zmiennych diagnostycznych przy wykorzystaniu współczynnika asymetrii jako metody badania ważności mierników, gdy zmienne są stymulantami, powinny się charakteryzować rozkładem prawostronnie asymetrycznym. Jest to gwarancją wysokiego różnicowania przez nie badanych obiektów. W niniejszym badaniu wszystkie potencjalne mierniki diagnostyczne były stymulantami. W ich przypadku większość charakteryzowała się rozkładem lewostronnie asymetrycznym. Wiązało się to ze specyfiką badanych obiektów oraz z metodologią wykorzystywaną przez Instytut Frasera przy budowaniu bazy danych, która pozwalała na ilościowe skwantyfikowanie relatywnie trudno mierzalnych zjawisk jakościowych, jakimi są charakterystyki poszczególnych elementów ładu instytucjonalnego. W przypadku wykorzystywanych w badaniu mierników oceniane kraje uzyskiwały wartości z przedziału od 0 do 10, gdzie wyższa wartość była tożsama $\mathrm{z}$ wyższą oceną dla badanego segmentu systemu instytucjonalnego. W niniejszym badaniu uwzględniono kraje Unii Europejskiej, które charakteryzują się relatywnie wysokimi ocenami dla systemów instytucjonalnych w porównaniu z pozostałymi krajami uwzględnionymi w bazie. Baza danych Instytutu Frasera jest tworzona dla ponad 120 krajów, w związku z tym kraje Unii Europejskiej osiągają w tym zestawieniu relatywnie wysokie wartości. Ponadto próby znalezienia alternatywnych mierników pozwalających na spójną metodologiczne ocenę systemów instytucjonalnych krajów dla całej Unii Europejskiej, dla okresu objętym badaniem są relatywnie trudne. Tym samym, ze względu na dominującą rolę kryteriów merytorycznych, w niniejszym badaniu wystąpiła konieczność rezygnacji z zastosowania kryterium formalnego dotyczącego rozkładu zmiennych diagnostycznych ${ }^{25}$.

W przypadku ostatniego kryterium - ważności informacyjnej (ocena stopnia skorelowania zmiennych) oraz zastosowaniu parametrycznej metody Hellwiga w celu wyselekcjonowania zmiennych reprezentantek w kolejnych latach należałoby rozważyć wyeliminowanie zmiennych przedstawionych w tabeli 2.

Tabela 2. Zmienne diagnostyczne niespełniające kryterium ważności informacyjnej

\begin{tabular}{|c|c|c|c|c|c|c|c|c|}
\hline Rok & 2001 & 2002 & 2003 & 2004 & 2005 & 2006 & 2007 & 2008 \\
\hline $\begin{array}{l}\text { Zmienne } \\
\text { eliminowane }\end{array}$ & $x_{i 6^{\prime}}, x_{i 9}$ & $x_{i 6^{\prime}} x_{i 9}$ & $\begin{array}{ll}x_{i 4}, & x_{i 5^{\prime}} \\
x_{i 6^{\prime}} & x_{i 9}\end{array}$ & $\begin{array}{l}x_{i 4^{\prime}} x_{i 5^{\prime}} \\
x_{i 6}, x_{i 9}\end{array}$ & $\begin{array}{cc}x_{i 4^{\prime}} & x_{i 5^{\prime}} \\
x_{i 6^{\prime}} & x_{i 9}\end{array}$ & $\begin{array}{cc}x_{i 4^{\prime}} & x_{i 5^{\prime}} \\
x_{i 6}, & x_{i 9^{\prime}} \\
x_{i 15}\end{array}$ & $\begin{array}{cc}x_{i 4^{\prime}} & x_{i 5^{\prime}} \\
x_{i 6^{\prime}} & x_{i 9^{\prime}} \\
x_{i 15}\end{array}$ & $\begin{array}{cl}x_{i 4^{\prime}} & x_{i 5^{\prime}} \\
x_{i 6^{\prime}} & x_{i 9^{\prime}} \\
& x_{i 15}\end{array}$ \\
\hline
\end{tabular}

Źródło: obliczenia własne.

25 Analogiczny problem autor badania napotkał w trakcie analiz efektywności instytucjonalnych działań krajów OECD w kontekście ich wsparcia dla wykorzystaniu potencjału nowej globalnej gospodarki wiedzy. Zob. A.P. Balcerzak, Państwo w realich, s. 289-290. 
Analiza wyników dla kryterium ważności informacyjnej prowadzi do wniosku analogicznego do tego, który można było wysnuć z oceny wyników kryterium wysokiej zmienności przestrzennej. Także w tym wypadku dostrzegalne są znamiona procesów integracyjnych $\mathrm{w}$ odniesieniu do różnych segmentów systemu instytucjonalnego krajów po rozszerzeniu z 2004.

Tym samym, ze względu na przyjęty cel pracy oraz interpretację merytoryczną wyników analizy dla kryteriów ważności informacyjnej potencjalnych mierników, pomimo formalnych wskazań przeprowadzonej analizy zdecydowano się nie eliminować żadnego $\mathrm{z}$ mierników ze zbioru potencjalnych zmiennych diagnostycznych.

Następnym etapem badania było doprowadzenie zmiennych diagnostycznych do porównywalności. W tym celu zastosowano klasyczną procedurę normalizacji bazującą na średniej arytmetycznej i odchyleniu standardowym (równanie 1), dzięki czemu uzyskano zmienne o średniej równej 0 i wariancji równej 1.

$$
x_{i j}:=\frac{x_{i j}-\bar{x}_{j}}{s_{j}},
$$

gdzie:

$x_{i j}$ - wartość $j$-tej zmiennej dla $i$-tego obiektu,

$\bar{x}_{j}-$ średnia arytmetyczna $j$-tej zmiennej,

$s_{j}$ - odchylenie standardowe $j$-tej zmiennej.

Ostatnim krokiem analizy było pogrupowanie badanych krajów przy użyciu metody Warda $\mathrm{z}$ wykorzystaniem odległości euklidesowej. Przyjęta procedura grupowania jest jedną $z$ najczęściej wykorzystywanych hierarchicznych metod klasyfikacji, natomiast odległość euklidesową wykorzystano ze względu na jej dobre właściwości matematyczne. W metodzie Warda do wyodrębnienia grup wykorzystywane jest podejście analizy wariancji, co sprzyja tworzeniu skupień o relatywnie małej wielkości oraz względnie dużych odległościach między ich centroidami. Metoda ta polega na sekwencyjnym zmniejszaniu liczby skupień w wyniku łączenia ich w grupy wyższego rzędu aż do uzyskania pełnej ich hierarchii. Punktem wyjścia całej procedury jest macierz odległości D między obiektami, z których każdy tworzy początkowo odrębne skupienie. Para skupień najmniej odległych od siebie jest łączona w jedno nowe skupienie, a następnie wyznaczana jest jego odległości od pozostałych skupień. $Z$ macierzy $D$ eliminowane są odległości związane z obiektami występującymi w nowym skupieniu, a wstawia się do niej odległości nowo powstałego skupienia od innych skupień, uzyskując w ten sposób nową macierz odległości. Algorytm ten jest powtarzany do momentu, gdy wszystkie obiekty utworzą jedno skupienie. Różnice pomiędzy hierarchicznymi 
metodami aglomeracyjnymi wynikają z odmiennych sposobów wyznaczania odległości między skupieniami. W przypadku metody Warda definiuje się ją jako różnicę między sumami kwadratów odchyleń odległości poszczególnych punktów od środka ciężkości grup, do których należąa ${ }^{26}$. Wyniki uzyskanego grupowania dla roku 2000, 2004 i 2008 zostały zaprezentowane w postaci dendrogramów na rysunkach od 1 do 3 .

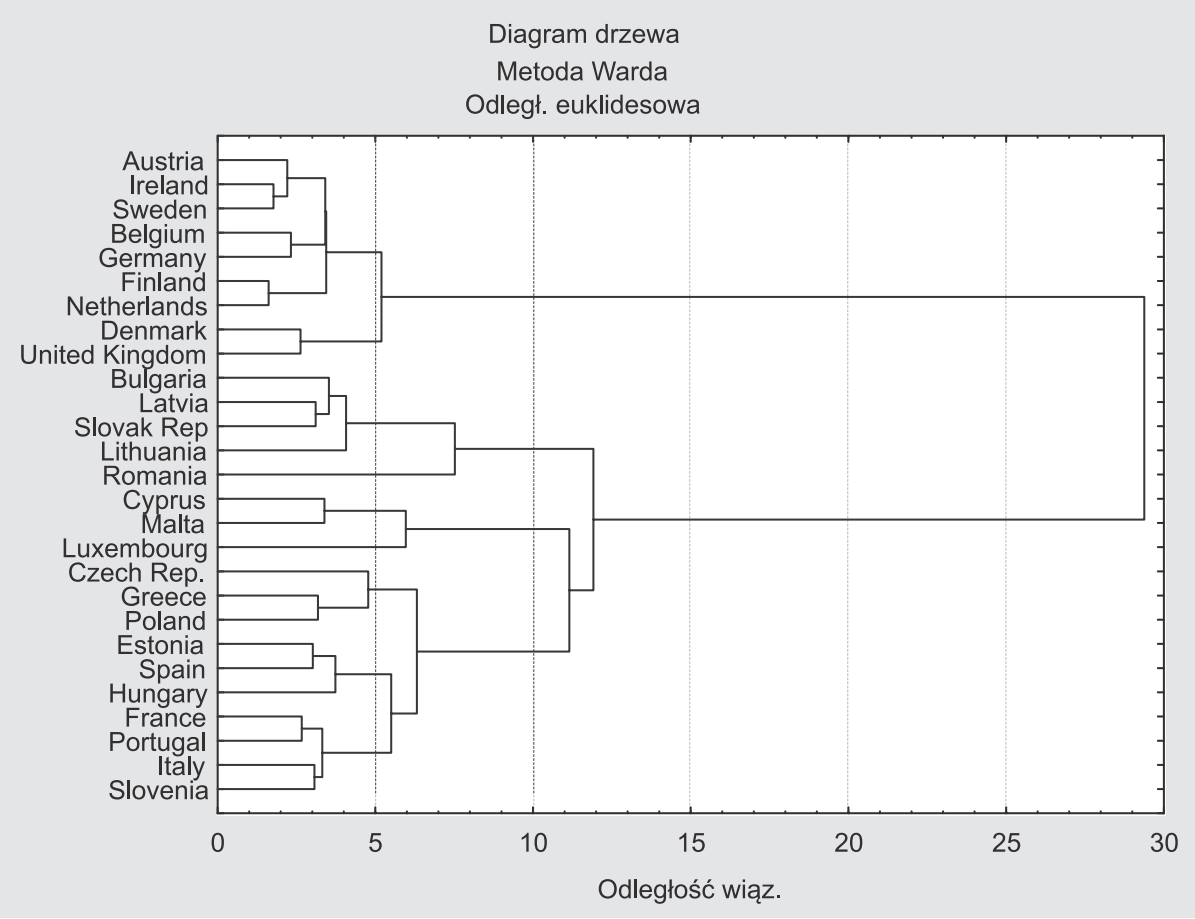

Rysunek 1. Dendrogramy grupowania krajów Unii Europejskiej ze względu na podobieństwa systemów instytucjonalnych metodą Warda dla roku 2000

Źródło: opracowanie własne na podstawie danych z bazy Instytutu Frasera w roku 2010 zob. J. Gwartney, J. Hall, R. Lawson, Economic Freedom of the World 2010 Annual Report, Fraser Institute 2010.

26 Zob. Statystyczne metody analizy, s. 88-96. 


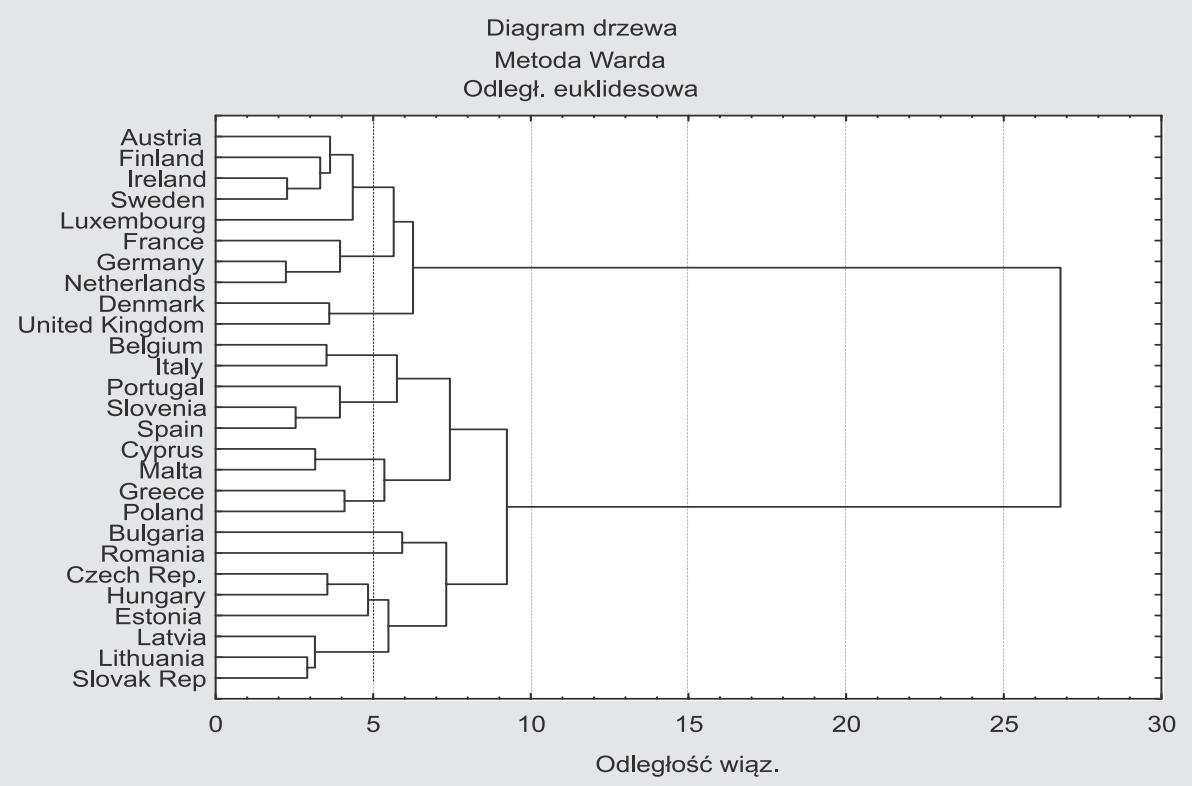

Rysunek 2. Dendrogramy grupowania krajów Unii Europejskiej ze względu na podobieństwa systemów instytucjonalnych metodą Warda dla roku 2004

Źródło: jak dla rys. 1.

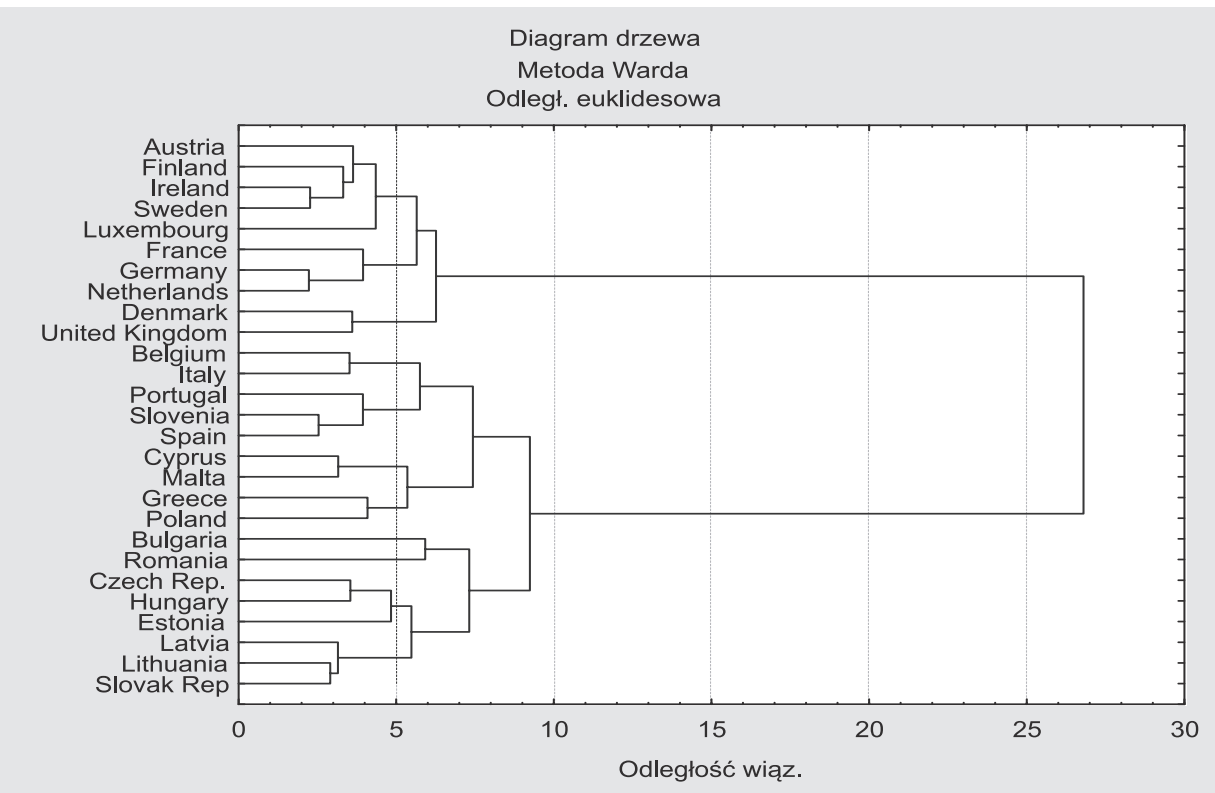

Rysunek 3. Dendrogramy grupowania krajów Unii Europejskiej ze względu na podobieństwa systemów instytucjonalnych metodą Warda dla roku 2008

Źródło: jak na rys. 1. 
W tabeli 3 przedstawiono wyodrębnione skupienia w latach 2000, 2004 oraz 2008.

Tabela 3. Wyodrębnione skupienia dla lat 2000, 2004 i 2008

\begin{tabular}{|c|c|c|}
\hline 2000 & 2004 & 2008 \\
\hline SKUPIENIE I & SKUPIENIE I & SKUPIENEI I \\
\hline Austria & Austria & Austria \\
\hline Irlandia & Finlandia & Irlandia \\
\hline Szwecja & Irlandia & Holandia \\
\hline Belgia & Szwecja & Niemcy \\
\hline Niemcy & Luksemburg & Finlandia \\
\hline Finlandia & Francja & Szwecja \\
\hline Holandia & Niemcy & Luksemburg \\
\hline Dania & Holandia & \\
\hline \multirow[t]{2}{*}{ Wielka Brytania } & Dania & \\
\hline & Wielka Brytania & \\
\hline SKUPIENIE II & SKUPIENIE II & SKUPIENIE II \\
\hline Bułgaria & Belgia & Cypr \\
\hline Łotwa & Włochy & Estonia \\
\hline Słowacja & Portugalia & Dania \\
\hline Litwa & Słowenia & \\
\hline Rumunia & Hiszpania & \\
\hline SKUPIENIE III & SKUPIENIE III & SKUPIENIE III \\
\hline Cypr & Cypr & Belgia \\
\hline Malta & Malta & Francja \\
\hline \multirow[t]{7}{*}{ Luksemburg } & Grecja & Portugalia \\
\hline & Polska & Wielka Brytania \\
\hline & & Słowenia \\
\hline & & Hiszpania \\
\hline & & Czechy \\
\hline & & Łotwa \\
\hline & & Węgry \\
\hline SKUPIENIE IV & SKUPIENIE IV & SkUPIENIE IV \\
\hline Czechy & Bułgaria & Malta \\
\hline Grecja & Rumunia & \\
\hline \multicolumn{3}{|l|}{ Polska } \\
\hline Estonia & SkUPIENIE V & SkUPIENIE V \\
\hline Hiszpania & Czechy & Bułgaria \\
\hline Węgry & Węgry & Litwa \\
\hline Francja & Estonia & Polska \\
\hline Portugalia & Łotwa & Słowenia \\
\hline Włochy & Litwa & Grecja \\
\hline \multirow[t]{2}{*}{ Słowenia } & Słowacja & Włochy \\
\hline & & Rumunia \\
\hline
\end{tabular}

Źródło: opracowanie własne na podstawie danych z bazy Instytutu Frasera w roku 2010 zob. J. Gwartney,

J. Hall, R. Lawson, Economic Freedom of the World 2010 Annual Report, Fraser Institute 2010. 


\section{ZAKOŃCZENIE}

Przeprowadzona analiza empiryczna $\mathrm{z}$ wykorzystaniem taksonomicznej hierarchicznej procedury grupowania bazującej na metodzie Warda potwierdza występowanie procesów integracyjnych w krajach Unii Europejskiej w odniesieniu do gospodarczego ładu instytucjonalnego. Już na etapie analizy ważności informacyjnej potencjalnych mierników diagnostycznych można wskazać dowody rosnącej integracji instytucjonalnej badanych krajów. Świadczyły o tym malejąca zmienność przestrzenna oraz rosnąca korelacja niektórych mierników diagnostycznych nasilające się po 2004 roku. Podobne wnioski mogą być wyciągane na podstawie analizy skupień dla roku 2000, 2004 i 2008. W 2000 r. można zauważyć, że z wyjątkiem Francji i Włoch kraje będące tzw. wiodącymi gospodarkami UE oraz kraje kandydujące do Wspólnoty tworzyły odrębne jednorodne skupienia. Analiza dla roku 2004 w przypadku tzw. nowych krajów uczestniczących w procesie integracji europejskiej ukazała wyraźny podział na kraje wstępujące do UE w tym roku oraz Rumunię i Bułgarię, które zostały włączone do Unii trzy lata później. W przypadku roku 2008 podział ten już nie występował, natomiast powstało m.in. skupienie grupujące w jednym zbiorze takie kraje, jak Belgia, Francja, Portugalia, Hiszpania i Wielka Brytania oraz Słowenia, Czechy, Łotwa, Węgry.

Należy jednak także zauważyć, że pomimo występowania procesów integracyjnych w analizowanym okresie cały czas można wskazać na grupę krajów dość jednorodnych w odniesieniu do porządku instytucjonalnego wspierającego wykorzystanie potencjału nowej globalnej gospodarki, które we wszystkich trzech latach były grupowane zawsze w pierwszym skupieniu, jak np. Austria, Irlandia, Holandia, Niemcy, Finlandia i Szwecja.

Proces integracji instytucjonalnej wspierającej wykorzystanie potencjału nowej globalnej gospodarki wiedzy należy ocenić pozytywnie. W warunkach przyspieszonej transformacji technologicznej oraz instytucjonalnej gospodarki światowej jego występowanie jest jednym $\mathrm{z}$ głównych determinantów utrzymania wysokiej konkurencyjności gospodarki Unii Europejskiej. W tym kontekście otwartą kwestią pozostaje problem jego pożądanego bądź też wystarczającego tempa dla utrzymania wysokiej konkurencyjności międzynarodowej Europy.

Przeprowadzone badanie empiryczne wskazuje, że pomimo potwierdzenia występowania integracji instytucjonalnej w krajach Wspólnoty cały czas można mówić o „Europie dwóch prędkości” - występowaniu grupy krajów, które szczególnie efektywnie reformują swoje gospodarki w odpowiedzi na globalne wyzwania (wspomniane Austria, Irlandia, Holandia, Niemcy, Finlandia i Szwecja) oraz pozostałych krajach prowadzących niezbędne reformy z pewnym opóźnieniem. Tymczasem ostatni międzynarodowy kryzys finansowy stanowiący katalizator dla 
problemów Grecji, Portugalii, które z kolei zagrażają stabilności gospodarki europejskiej, potwierdza, że niskie tempo integracji instytucjonalnej oraz niewystarczająca dynamika konwergencji realnej krajów członkowskich Unii Europejskiej mogą stanowić jedno z kluczowych zagrożeń dla rozwoju gospodarczego Europy.

\section{BIBLIOGRAFIA}

Ardagna S., Lusardi A., Explaining International Differences in Entrepreneurship: the role of Individual Characters and Regulatory Constraints, NBER Working Papers Series, Working Paper 14012, 2008, May.

Atkinson R.D., Correa D.K., The 2007 State New Economy Index. Benchmarking Economic Transformation in the States, Kauffman Foundation, „The Information Technology and Innovation Foundation" 2007, February.

Balcerzak A.P., Pañstwo w realiach „nowej gospodarki”. Podstawy efektywnej polityki gospodarczej w XXI wieku, Wydawnictwo Adam Marszałek, Toruń 2009.

Balcerzak A.P., Structure of Financial Systems and Development of Innovative Enterprises with High Grow Potential, Global Challenges and Politics of the European Union-Consequences for the "New Member States", Prace Naukowe Uniwersytetu Ekonomicznego we Wrocławiu, nr 59, red. M. Piotrowska, L. Kurowski, Wrocław 2009.

Balcerzak A.P., Wptyw dziatalności regulacyjnej państwa w obszarze kreowania tadu konkurencyjnego na rozwój nowvej gospodarki, [w:], Aktywność regulacyjna państwa a potencjat rozwojowy gospodarki, red. A.P. Balcerzak, M. Moszyński, Polskie Towarzystwo Ekonomiczne, Oddział w Toruniu, Toruń 2009.

Balcerzak A.P., Rogalska E., Government's Effectiveness in Creating Institutional Conditions for Entrepreneurship in Central and Eastern Europe in the Years 2004-2010, [w:] Policies for Improving Growth Potential: International Perspective, red. A.P. Balcerzak, Wydawnictwo Naukowe UMK, Toruń 2010.

Doing Business 2011. Making Difference for Entrepreneurs, The International Bank for Reconstruction and Development/The World Bank, Washington 2010.

Gwartney J, Hall J., Lawson R., Economic Freedom of the World 2010 Annual Report, Fraser Institute 2010.

Kapitat intelektualny i jego ochrona, red. E. Okoń-Horodyńska, R. Wisła, Instytut Wiedzy i Innowacji, Warszawa 2009.

North D.C., Economic Performance through Time, „American Economic Review” 1994, vol. 84 , No. 3.

North D.C., Institutions, Transactions Cost and Productivity in The Long Run, Economic History 9309004, Ecin WPA, 1993, http://ideas.repec.org/e/prio11.html (28.03.2007).

Okoń-Horodyńska E., Przedsiębiorczość jako niewwykorzystane źródto sukcesu polskiej gospodarki, Polskie Towarzystwo Ekonomiczne, Warszawa 2009.

Piech K., Wiedza i innowacje w rozwoju gospodarczym: w kierunku pomiaru i wspótczesnej roli pañstwa, Instytut Wiedzy i Innowacji, Warszawa 2009. 
Pietrucha J., Ramy instytucjonalne polityki pieniężnej-teoria i pomiar, Wydawnictwo Akademii Ekonomicznej w Katowicach, Katowice 2008.

Statystyczne metody analizy danych, red. W. Ostasiewicz, Wydawnictwo Akademii Ekonomicznej im. Oskara Langego, Wrocław 1998

Taksonomiczna analiza przestrzennego zróżnicowania poziomu życia w Polsce w ujęciu dynamicznym, red. A. Zeliaś, Wydawnictwo Akademii Ekonomicznej, Kraków 2000.

Stel A., Storey D., Thurik A., The Effect of Business Regulations on Nascent and Young Business Entrepreneurship, „Small Business Economics” 2007, vol. 28, No. 2, s. 171-186.

Strzała K., Przechlewski T., Ekonometria inaczej, Wydawnictwo Uniwersytetu Gdańskiego, Gdańsk 1995.

Williamson O., The New Institutional Economics: Taking Stock, Looking Ahead, "Journal of Economic Literature” 2000, vol. XXXVIII, September.

\section{INSTITUTIONAL INTEGRATION IN THE EUROPEAN UNION. SUGGESTION FOR MEASUREMENT}

SUMMARY

The last decade has been a period of accelerated integration in Europe. A tangible manifestation of this was the biggest ever enlargement of the EU in 2004 and its next enlargement in 2007. Therefore the aim of this study is a formalized empirical evaluation of the phenomenon of integration in the case of EU countries in the sphere of economic institutional order in the first decade of the twentieth century. Because of the fact that institutional systems should be treated as multidimensional phenomena, in this study generally recognized taxonomic tools were used - a hierarchical classification method, which made it possible to obtain some homogeneous subsets of countries classified on the basis of institutional system similarities in each year. The study was based on annual data from the period 2000-2008 for 27 countries that are members of the EU. It made it possible to capture a period of four years before and four years after the biggest enlargement of the EU. The main research problem of this study amounted to the question: whether in the analyzed period one can speak about the process of growing similarities in the sphere of institutional order in case of so called old and new EU member states? The study confirms the existence of integration processes in relation to economic governance and institutional order. 
